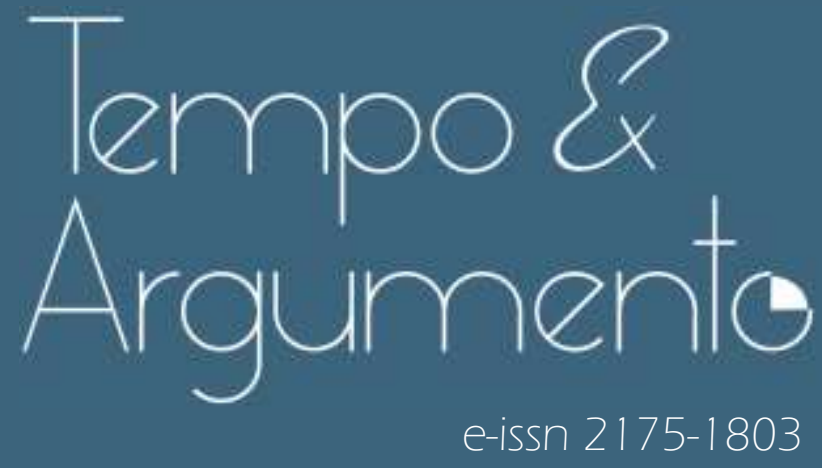

\title{
Tempo-do-agora (Jetztzeit), História do Tempo Presente e Guerra do Contestado
}

- Rogério Rosa Rodrigues

Doutor em História Social pela Universidade Federal do Rio de Janeiro UFRJ).

Professor do Programa de Pós-Graduação em História da Universidade do Estado de Santa Catarina (UDESC).

Florianópolis, SC - BRASIL

lattes.cnpq.br/1738939950525949

rogerclio@gmail.com

(D) orcid.org/0000-0002-5189-7095

Para citar este artigo:

RODRIGUES, Rogério Rosa. Tempo-do-agora (Jetztzeit), História do Tempo Presente e Guerra do Contestado. Tempo e Argumento, Florianópolis, e0 1 11, 2021. Número especial.

do) http://dx.doi.org/10.5965/21751803ne2021 e0111 


\title{
Tempo-do-agora (Jetztzeit), História do Tempo Presente e Guerra do Contestado ${ }^{1}$
}

\begin{abstract}
Resumo
Qual é a relação entre os ideais de uma comunidade igualitária do início do século XX com desenhos infantis do século XXI? É possível abordar a História do Tempo Presente a partir da perspectiva de um tempo suspenso, que não é processo nem repetição? Por meio do depoimento de um frei alemão, de 1913, e de 3 desenhos infantis produzidos em 2020, ambos sobre a Santa Irmandade do Contestado, proponho refletir acerca das possíveis conexões entre história do tempo presente e as categorias de Walter Benjamin denominadas "tempo-do-agora" (Jetztzeit) e "imagem dialética". Minha hipótese é a de que os ideais da Santa Irmandade do Contestado reaparecem em desenhos infantis produzidos por estudantes de escolas de um dos municípios que foram palco do conflito. Ao fim, proponho ampliar o repertório de análise e reflexões a respeito das múltiplas temporalidades que atravessam o que, na tradição historiográfica francesa, tem sido denominado História do Tempo Presente.
\end{abstract}

Palavras-chave: Tempo-do-agora; história do tempo presente; imagem dialética; ensino de história; Guerra do Contestado.

\section{Now-time (Jetztzeit), History of the Present Time and Contestado War}

\begin{abstract}
What is the relationship between the ideals of an egalitarian community in the beginning of the 20th century and children's drawings in the 21st century? Is it possible to address the History of the Present Time from the perspective of a suspended time, which is neither a process nor a repetition? Through the testimony of a German friar, made in 1913, and 3 children's drawings produced in 2020, both about the Santa Irmandade do Contestado, I propose to think through the possible connections between history of the present time and Walter Benjamin's categories called 'now-time' (Jetztzeit) and 'dialectical image.' My assumption is that the ideals of the Santa Irmandade do Contestado reappear in children's drawings produced by school students in one of the municipalities that were the ground of the conflict. Finally, I propose to expand the repertoire of analysis and reflections on the multiple temporalities that go through what, in the French historiographic tradition, has been called History of the Present Time.
\end{abstract}

Keywords: Now-time; history of the present time; dialectical image; history teaching; Contestado War.

\footnotetext{
Este artigo faz parte da pesquisa intitulada "A Guerra do Contestado no ensino de história do Brasil: memória, história e conflitos", projeto realizado com apoio financeiro da FAPESC.
} 
Os fragmentos históricos são o resto de uma explosão.

O presente do passado.

Susan Buck-Moors

\section{Introdução}

Em 12 dezembro de 1913, um frei alemão se dirigiu ao vilarejo de Taquaruçu, região do planalto catarinense, para convencer homens e mulheres a abandonarem sua comunidade sob o pretexto de que ali existia uma organização contra as leis da Igreja e da República. Seu nome era Rogério Neuhaus. A comunidade que visitou tinha sido recém-fundada por antigos fiéis de um curandeiro chamado José Maria, doravante identificada como Santa Irmandade do Contestado. O ideal coletivo da Santa Irmandade tinha como princípio o lema "quem tem mói, quem não tem mói também. E assim todos ficam iguais", ou seja, nessa sociedade, todos teriam comida, terra para plantar e dignidade. Seus membros acreditavam na ressurreição do monge José Maria, morto há mais de um ano, após ser perseguido por lideranças políticas catarinenses e ser atacado pelo regimento de segurança do Paraná em região de fronteira entre os dois estados ${ }^{2}$.

Na Santa Irmandade erguida em Taquaruçu, as decisões eram compartilhadas e um complexo sistema de ritualização da vida cotidiana foi montado, incluindo rezas, leituras coletivas, divisão de tarefas e trabalho compartilhado entre os pares. É contra esse modelo de sociedade, ao mesmo tempo política e espiritual, que Frei Rogério Neuhaus mobilizava sua energia e sua autoridade. Seu argumento era o de que, como pastor vocacionado, preocupava-se e queria o bem do seu rebanho; portanto, sabendo da iminência de uma repressão policial à comunidade, antecipara-se para dissuadir as pessoas a voltarem para suas casas. Não sabemos ao certo quantas pessoas estavam reunidas em Taquaruçu naquele dia 12 de dezembro de 1913, mas, pelo relato

\footnotetext{
${ }^{2}$ O confronto ocorrera em 22 de outubro de 1912, no episódio que entrou para os anais da história como Batalha do Irani. Esse episódio foi analisado em detalhes pelos pesquisadores Gabriel Kunrath (KUNRATH, G. C. Não tivemos outro jeito, ou morríamos ou nos defendíamos: uma análise acerca da Batalha do Irani (1912). 2020. Dissertação (Mestrado em História) Universidade Federal de Pelotas, Pelotas, 2020) e por Celso Vianna Bezerra de Menezes (2015).
} 
apresentado pelo frei franciscano, parecem ser algumas poucas dezenas, incluindo as lideranças por ele identificadas como fanáticas.

A Santa Irmandade de São José e São João ${ }^{3}$ Maria tinha sido criada como alternativa à vida de exploração econômica e política, naquele contexto, representadas pelo poderio de coronéis, pela presença da construtora de uma estrada de ferro, bem como pela madeireira e empresa de colonização de terras instaladas na região4. A Igreja, outro elo de dominação nesse conjunto, apresentava-se como mediadora entre Deus e os homens, mas também entre as autoridades oficiais e os sujeitos comuns.

É nesse contexto que Frei Rogério Neuhaus se dirigiu à recém-fundada comunidade de Taquaruçu. O diálogo que ele travou com pessoas da Santa Irmandade serve como ponto de partida para refletirmos sobre alguns elementos centrais da luta rebelde dos fiéis de João e José Maria, episódio histórico mais conhecido como Guerra do Contestado. Esse episódio histórico tem como marco oficial o período compreendido entre 1912 e 1916, geralmente associado ao caráter repressivo do Estado brasileiro contra um grupo de rebeldes que habitavam uma região disputada (contestada) pelos estados do Paraná e de Santa Catarina. Tal associação entre o caráter repressivo do Estado, as forças políticas e econômicas e a resistência dos rebeldes fazem parte da história da Santa Irmandade, mas creio que coloca os ideais dos rebeldes em um campo de atuação que acaba destacando mais as ações dos agentes repressores do que as propostas, ideias e valores da própria comunidade.

\footnotetext{
Embora os fiéis tivessem se reunido para celebrar a possível ressurreição de José Maria, o curandeiro morto na Batalha do Irani em 1912, eles também celebravam a força da santidade de outros andarilhos que atendiam pelo nome de João Maria. Eles circularam pela região desde meados do século XIX com práticas semelhantes: benzer, indicar medicamentos, batizar as crianças, aconselhar os familiares. A presença desses andarilhos configurou uma tradição que a antropóloga Tânia Welter (2018) denominou de joanina, ou seja, uma crença firmada nas profecias e práticas dos monges João e José Maria, que se encontram vivas até a atualidade.

${ }^{4}$ Há uma vasta historiografia que dá ênfase a esses sujeitos e instituições. Ela será mobilizada ao longo do texto, por ora cumpre destacar 5 autores com obras de referência: Oswaldo Rodrigues Cabral (CABRAL, Oswaldo Rodrigues. A campanha do Contestado. 2. ed. Florianópolis: Lunardelli, 1979); Maurício Vinhas de Queiroz (QUEIROZ, Maurício Vinhas de. Messianismo e conflito social: a guerra sertaneja do Contestado, 1912-1916. 3. ed. São Paulo: Ática, 1981); Duglas Teixeira Monteiro (MONTEIRO, Duglas Teixeira. Os errantes do novo século. São Paulo: Duas Cidades, 1974); Paulo Pinheiro Machado (MACHADO, Paulo Pinheiro. Lideranças do Contestado. Campinas: UNICAMP, 2004); e Márcia Janete Espig (ESPIG, Márcia Janete. Personagens do Contestado: os turmeiros da estrada de ferro São Paulo - Rio Grande (1908-1915). Pelotas: Editora Universitária/UFPEL, 2011).
} 
Sem negar, nem minimizar o poder de destruição política e simbólica das forças repressivas do Estado, proponho refletir sobre a força do passado no presente, com destaque para a forma como os clamores e projetos de mundo da Santa Irmandade irromperam no nosso presente e ganham relevo e destaque em desenhos infantis. Como o ponto de partida dessa análise se ampara em depoimento elaborado pelo inimigo dos homens e mulheres que construíram a Santa Irmandade, reivindico o que Walter Benjamin chamou de análise a contrapelo. Michel Löwy (2005, p. 74) definiu essa proposta de análise como "ir contra a corrente da versão oficial da história, opondo-lhe a tradição dos oprimidos". O desafio é o de arrancar das narrativas dos vencedores, nesse caso, a narrativa de frei Rogério Neuhaus, estratégias, táticas e experiências dos homens e mulheres que viviam na cidade santa de Taquaruçu.

Para além da experiência rebelde registrada no texto do franciscano, cumpre pensar como essa luta reaparece, um século depois, em narrativas feitas por crianças que vivem na mesma região. Minha hipótese é a de que os ideais da Santa Irmandade que foram reprimidos na época do conflito reaparecem em desenhos infantis em um contexto de perigo e morte que assombra nosso século imerso em um caos político e sanitário, que não deixa de ser também moral, econômico e ambiental. Nesse aspecto, reivindico 2 categorias articuladas por Walter Benjamin ao construir suas teses sobre o conceito de história, a saber: o tempo-do-agora (Jetztzeit) e a imagem dialética. Por fim, destaco a pertinência dessas 2 categorias para ampliarmos o repertório de análise e reflexões no que se refere às múltiplas temporalidades que atravessem o que, na tradição historiográfica francesa, tem sido denominado como História do Tempo Presente $(\mathrm{HTP})$.

\section{Vivendo em outro século}

A Santa Irmandade pode ser pensada como a constituição de uma comunidade de iguais, de caráter político-religioso rebelde, firmada na crença dos monges populares e dos santos tradicionais, que desejava fundar um novo tempo no mundo. Mundo novo entendido como uma sociedade regida por nova temporalidade, mas nem por isso fora do presente em que vivia. A vida nesse novo tempo do mundo exigia mais do que a contemplação e o louvor aos 
preceitos sagrados. Era preciso refundar a sociedade, estabelecer nova rotina, novos rituais, novo modelo de organização.

Como observou Duglas Teixeira Monteiro (1974), os homens e mulheres do Contestado entendiam que aguardar o novo mundo era lutar por ele. Mais do que isso, implicava torná-lo concreto no tempo e no lugar que eles escolheram. Não era, portanto, uma comunidade construída para esperar a salvação por si própria. Nosso desafio, como historiadores e historiadoras do século XXI, é identificar esses valores comuns nos documentos elaborados por quem desejava reprimir aquela comunidade. É por isso que o relato do encontro de um frei franciscano, de origem alemã, com os habitantes de Taquaruçu se revela importante, uma vez que, mesmo sendo um registro da memória do vencedor, abre-nos a possibilidade de vislumbrar os sonhos, desejos e concepções de mundo formulados pelos que ali habitavam. O que a narrativa do religioso nos mostra é, entre outras coisas, a força política e social da comunidade, bem como seu enraizamento em crenças e argumentos extremamente complexos. Vale a pena acompanhar, pari passu, a reprodução do diálogo que o representante da Igreja Católica faz desse contato, pois parte da tentativa de romper com a narrativa do vencedor e localizar algumas questões próprias da Santa Irmandade; inclui também desconstruir as estratégias retóricas e narrativas que o frei construiu e que se cristalizaram na memória oficial do acontecimento.

\section{Cena 1: "Vocês serão mortos à bala e à espada"}

Frei Rogério: Quero o bem para vocês, por isso aqui cheguei ontem, vim debaixo da chuva terrível, durante a noite, arriscando minha própria vida que estou pronto a dar por vocês. É que os vejo em perigo gravíssimo. Convido-os a que venham assistir ao S. Sacrifício da Missa e em seguida cada qual volte para sua casa a cuidar de seu trabalho e de sua família. Si o não fizerem, o governo intervirá, e vocês serão mortos à bala e à espada (SINZIG, 1934, p. $72)^{5}$.

\footnotetext{
O relato de Frei Rogério Neuhaus foi originalmente publicado nas páginas da revista Vozes, sob o título "Os fanáticos do sertão: deploráveis frutos da educação religiosa (correspondência especial para Vozes de Petrópolis, por uma testemunha ocular)", Curitibanos, 12/12/1913. No ano de 1934, esse relato foi compilado e publicado em livro por outro frei da mesma ordem religiosa. Seu nome era Pedro Sinzig. Esta foi a versão consultada.
} 
O relato de Neuhaus começa com a própria afirmação de sua autoridade. Ao dizer que estava pronto para dar a vida pelos homens e mulheres, ele se inclui na linhagem dos mártires da Igreja Católica, mas também se iguala ao curandeiro José Maria que morrera, havia um ano, por defender seus companheiros e companheiras no episódio histórico denominado Batalha do Irani. O convite/intimação para assistirem à missa é outra tentativa de intimidar os membros da comunidade e anular a autoridade do monge curandeiro, que regia a formação daquela irmandade. A frase termina com uma ameaça: ou aceitam a ordem ou serão mortos.

\section{Cena 2: "Aqui ninguém sofre"}

O velho Euzébio respondeu:

- Aqui não posso responder coisa alguma: só nosso chefe e comandante o pode fazer. [...] - Nós estamos debaixo da proteção de Nossa Senhora, graças a Deus!

- Então apresentou-se-me o tal chefe e comandante o filho do Euzébio Ferreira dos Santos, de rosto evidentemente alucinado, e que foi dizendo à queima roupas:

- Que quer o Sr. aqui? Retire-se, seu cachorro, que sinão apanha! Logo grande número de indivíduos o rodeou, todos armados de espadas e grandes facões.

- Quem é o Sr.? Perguntei por minha vez.

- Eu sou quem manda aqui.

- Então tenha a bondade de mandar a esse povo todo que se retire dessa região, porque doutra forma todo ele padecerá.

- Não. Aqui ninguém sofre. Só o sr. morrerá aqui mesmo (SINZIG, 1934, p. 72).

Para além das frases pejorativas que o religioso escolheu para denominar as pessoas (alucinados, fanáticos, sujeitos ameaçadores), interessa reter o que podemos apreender da organização e da visão de mundo dessa comunidade. A estrutura social era composta por uma liderança, nesse caso, um adolescente. Neuhaus fala dos avós do menino Manoel, mas somos informados por outros depoimentos de época que havia também pessoas mais velhas e experientes que o aconselhavam, assim como uma guarda de honra chamada Pares de França ${ }^{6}$ que possivelmente estava em organização nesse primeiro momento da

\footnotetext{
${ }^{6}$ Os chamados Pares de França eram uma guarda especial criada pelo curandeiro José Maria no momento em que conviveu com os homens e mulheres que o seguiam. Na segunda Taquaruçu,
} 
cidade santa de TaquaruçuT. Portanto, embora Manoel fosse o comandante, sabemos que, na Santa Irmandade, esse comando não possuía poderes ilimitados. Basta observar a voz ativa de homens e mulheres que aparecem nesse relato para verificarmos que se trata de um comando que consulta e decide de forma coletivå ${ }^{8}$ Não menos importante é a presença dos facões e espadas relatados nessa narrativa. Eles eram de madeira e dão testemunho do caráter ritual na forma de organização político-militar da Santa Irmandade. Ritualização que instituía uma nova rotina para o cotidiano de homens e mulheres ali presentes. Não havia uma só atividade que não fosse ritualizada, ou seja, que não fosse ressignificada de acordo com a nova ordem de mundo desejada. Dentro dessa nova rotina, instituída pela lógica de rompimento com o tempo de opressão anterior, o poder dos padres estava anulado. Eles não teriam mais de acatar suas ordens, tampouco parecem temer suas ameaças.

\section{Cena 3: "Os padres não valem nada"}

Vendo eu a atitude ameaçadora dos fanáticos, com seus facalhões e espadas erguidas, redargui:

- Os senhores devem respeitar os padres, que são os ministros de Deus. Nosso Senhor nos observa, e si tocarem sequer em mim certo é que os castigará a todos.

Então começaram eles a lanhar a terra com as afiadas armas, gritando:

- Morra!

Repeti:

- Respeitem o Padre!

Ao que o comandante respondeu:

Devemos respeitar os padres de boa vida, porém o Sr. É um corvo (referindo-se a mim), um ladrão de estrada que andou nos bailes da Estrada de Ferro do Rio do Peixe.

essa guarda será recuperada e, ao longo dos anos, assumirá funções diferentes. Para um estudo mais detalhado dos pares de França, ver o estudo de Márcia Janete Espig: ESPIG, Márcia Janete. A presença da gesta carolíngia no movimento do Contestado. Canoas/RS: [s. n.], 2002.

Essa é a segunda Taquaruçu, isso porque antes de morrer, em outubro de 1912, o curandeiro José Maria estivera na região a convite do velho Euzébio e sua família. Ele deixou a comunidade após sofrer perseguição política. Um ano após sua morte, a nova Taquaruçu é erguida pelos antigos fiéis. Um relato minucioso e bem documentado sobre a primeira Taquaruçu e a figura de José Maria pode ser encontrado na dissertação de Mestrado de Gabriel Kunrath (KUNRATH, G. C. Não tivemos outro jeito, ou morríamos ou nos defendíamos: uma análise acerca da Batalha do Irani (1912). 2020. Dissertação (Mestrado em História) - Universidade Federal de Pelotas, Pelotas, 2020).

8 Para outros detalhes sobre a trajetória, a autoridade e as funções de liderança no Contestado, ver a pesquisa de Paulo Pinheiro Machado (2004) e Cristina Dallanora (2020). 


\section{$[\ldots]$}

Neste momento, a mãe do comandante esbravejou:

- Os padres hoje já não valem mais nada!

Enquanto o velho Euzébio, erguendo um velho espadagão acrescentava:

- Nós estamos em um outro século: Liberdade! (SINZIG, 1934, p. 72).

A não submissão à autoridade do padre é expressa de forma radical. É dito que ele não vale nada. Isso porque, além de ser chamado de cachorro e de corvo, foi identificado como sujeito de vida errante, um homem de boa vida, um ladrão de estrada. Não deixa de ser importante registrar que essas representações negativas - relacionadas à morte (corvo), à farra e boa vida (bailes) desembocam todas no fato de serem conectadas com a estrada de ferro do Rio do Peixe, ou seja, com a materialização da companhia ferroviária que representava a modernidade econômica, mas que na prática da vida local expropriou terras, explorou a mão de obra dos habitantes locais e ainda subsidiou a construção de uma das maiores madeireiras e empresas de colonização de terras daquela região ${ }^{9}$. Foi contra esse mundo que os fiéis se insurgiram. A liberdade por eles aclamada afirmava que, no interior da cidade santa, ninguém morreria, ninguém passaria fome, ninguém seria explorado. O novo século seria construído coletivamente no e para o presente. Seus habitantes não admitiriam mais receber ordens de padres, tampouco se submeteriam à exploração da estrada de ferro e tudo que ela representava.

Cena 4: "Vá agora dizer a seus parceiros o que viu aqui"

- Se o senhor não aceitar os meus conselhos e se não retirar, digo-lhe o meu último adeus em vida, porque o sr. vai morrer.

$[\ldots]$

- Não faça isso!

\footnotetext{
9 Trata-se da Southern Brazil Lumber and Colonization Company, uma multinacional de grande poder político e econômico na região. Sobre ela, inúmeros estudos foram feitos, dentre os quais destaco: Alexandre Assis Tomporoski (TOMPOROSKI, Alexandre Assis. O polvo e seus tentáculos: a Southern Brazil Lumber and Colonization Company e as transformações impingidas ao planalto contestado, 1910-1940. 282 p. Tese (Doutorado em História) - Universidade Federal de Santa Catarina, Centro de Filosofia e Ciências Humanas, Florianópolis, 2013); Todd Diacon (DIACON, Todd A. Millenarian vision, capitalist reality: Brazil's Contestado rebellion, 1912-1916. Durham: Duke University Press, 1991); e Delmir Valentini (VALENTINI, Delmir. Memórias da Lumber e da Guerra do Contestado. Porto Alegre: Letra \& Vida; Chapecó: Ed. UFFS, 2015).
} 
E ele não o fez. Vendo eu, porém, que não podia convencer de seu erro esses fanáticos, retirei-me por minha vez, enquanto o velho gritava-me:

- Corvo!

Ao passo que a mulher berrava:

- Vá agora dizer a seus parceiros o que viu aqui.

E depois soube que a tal mulherzinha dissera que melhor teria sido assassinar-me ali mesmo (SINZIG, 1934, p. 72).

Não se pode deixar de registrar nesse depoimento o papel da mulher. Querubina aparece mais de uma vez e sempre de forma muito afrontosa. É ela a afirmar que ali naquela comunidade, a batina do padre - ou melhor, o poder da Igreja Católica - não encontrava guarida. Ainda que estivesse se referindo a um tipo específico de religioso (os de boa vida, os ladrões de beira de estrada, os que frequentavam os bailes da estrada de ferro), não deixa de ser uma ruptura importante. Se a Santa Irmandade se via como uma comunidade regida por santos católicos, como compreender a anulação do poder dos religiosos oficiais? Nesse caso, é preciso registrar que Querubina e seu marido, Euzébio, eram antigos fiéis do monge José Maria. Eles o conheceram em vida e chegaram a hospedá-lo. Portanto, estavam entre os antigos e mais importantes crentes em sua santidade.

Se levarmos em conta que o novo tempo do mundo era preparado sob inspiração e orientação de José Maria, podemos afirmar que a autoridade máxima daquela comunidade, portanto, era o monge. Ele se fazia presente por meio de sonhos e sinais da natureza e governava junto com São Sebastião e São Jorge. Vestígios que eram interpretados e repassados para os fiéis. Por isso, frei Rogério começou sua investida retórica afirmando a sua autoridade e a da Igreja acima de tudo.

Isso nos ajuda a compreender a ruptura com a Igreja, mas não nos situa na postura radical de Querubina, que, além de confrontar-se retoricamente com Frei Rogério, chega a propor a sua execução. Essa proposta estava fundamentada em sua intuição de que o frei entregaria todos para as autoridades policiais. Mais do que isso, que ele se aliaria a coronéis, militares e jagunços no combate à Santa 
Irmandade. Sua voz, praticamente se igualando à do comandante geral, termina dizendo ao religioso: parta e anuncie para os outros o que presenciou aqui ${ }^{10}$.

\section{Armando o cenário}

São muitos os detalhes a explorar nessa conversa, reproduzida, vale relembrar, pela pena do inimigo. Entretanto, para os argumentos deste texto, destaco:

1. A unidade da Santa Irmandade estava firmada no poder dos santos. No documento, reivindicou-se a Virgem Maria, mas em outros momentos são convocados São Sebastião, São Jorge, São José Maria e São João Maria;

2. A ideia de fundação de uma nova ordem temporal, que aparece na resposta imediata dessa comunidade estar em outro século, aquele de rompimento com as estruturas políticas e religiosas que os subordinavam aos elementos nefastos da vida. O grito "Liberdade!", pronunciado pelo velho Euzébio, parece ecoar um desejo coletivo que não se assenta apenas na expectativa dos presentes. São séculos de dominação pela exclusão da propriedade da terra, de exploração econômica, política e religiosa que clamava por liberdade junto a sua voz. No novo século implantado pelos homens e mulheres dessa comunidade, não haveria mais lugar para padres exploradores de boa

\footnotetext{
${ }^{10}$ Não é o caso de idealizar ou romantizar o papel das mulheres no Contestado. O machismo era, e é, estrutural no interior da Santa Irmandade. Como bem ressaltou Paulo Pinheiro Machado: "especial destaque deve ser dado à invenção do "Quadro Santo" ou da "Cidade Santa", o que se justifica pela criação de novo projeto de sociedade defendido pelos sertanejos, suas características comunitárias e anticapitalistas expressamente formuladas. No entanto, o "Quadro Santo" vivia com o recrudescimento de normas de conduta extremamente rígidas, baseadas na autoridade dos homens e dos mais velhos, mesmo quando eram as crianças videntes e mulheres que se colocavam no centro decisório do poder local. Não é um ambiente a ser idealizado, já que relações machistas e de violência de gênero eram recorrentes, tanto nos redutos, como na sociedade circundante. A recuperação de uma experiência social criativa não deve ser idealizada a ponto de encobrir problemas que existem em quaisquer sociedades" (MACHADO, 2017, p. 77). No entanto, vale destacar que foram as mulheres as maiores devotas de João e José Maria e que graças a elas a crença no monge se mantém atual no planalto catarinense até hoje, tal como podemos constatar no documentário Terra Cabocla, dirigido por Márcia Paraíso (PARAíso, Márcia. Terra Cabocla. Florianópolis: Plural Filmes, 2015).
} 
vida. Talvez por isso o frei - e aparentemente todos aqueles que a ele se assemelhassem - era identificado com um pássaro relacionado à morte (corvo);

3. A completa ritualização das atividades dentro dessa irmandade de tempo novo que aparece, em alguns elementos, destacada pelo frei: o uso dos facões e espadas de madeira, a forma como as decisões eram tomadas, a liderança conferida a um menino que hoje identificaríamos como um adolescente, a forma como os facões e espadas riscavam o chão e eram erguidos para o céu;

4. O último elemento que destaco é a identificação espacial da estrada de ferro como lugar de abrigo do mal: os bailes frequentados por corvos, exploradores, pessoas ruins. Como um dos ícones do progresso e da modernidade do final do século XIX e início do XX, a Estrada de Ferro São Paulo-Rio Grande levou aos homens e mulheres do planalto catarinense uma sucessão de problemas que começa com a desapropriação das terras de antigos posseiros, passa pelo conluio que os diretores fizeram com fazendeiros da região, até a construção da Southern Brazil Lumber and Colonization Company, empresa madeireira e colonizadora estrangeira, que além de devastar a madeira nativa e acabar com a economia local, destinou quase que exclusivamente a venda de terras para imigrantes e migrantes europeus ou de origem europeia.

As experiências traumáticas da desapropriação de terras e de exploração de mão de obra vividas por alguns sujeitos da Santa Irmandade os fazia pressentir o que significava a capitulação proposta pelo religioso franciscano: prisões, humilhação e, no limite, a interrupção desse tempo novo por eles inaugurado coletivamente.

O que apreendemos nesse documento, além da organização social e ideais de comunidade da Santa Irmandade, é um projeto de interrupção daquilo que Ivone Gallo (1999) chamou de um sonho igualitário. A tentativa de sequestro, feito pelas autoridades oficiais, do direito de os fiéis viverem em uma nova comunidade, aquela do novo século. Eles tinham não apenas ideais, como 
organização social próprios. Eles identificavam seus inimigos e desejavam romper com os laços antigos que os prendiam aos coronéis e ao jugo de empresas de colonização de terras e de exploração da madeira e da mão de obra local, tais como a Brazil Railway Company e todas as suas empresas subsidiárias.

É a força dessas propostas, ressaltadas por mim na interpretação desviante testada acima, que proponho imobilizar instantaneamente aquele momento para poder reconhecer parte dos ideais, ali presentes 107 anos depois, isto é, no ano em que uma pandemia travou os freios de parte da locomotiva socioeconômica que rege o planeta. Reaparecimento ocorrido na mente de outros sujeitos (crianças), mediado por outra instituição (escola) e materializado em outro tipo de documento (desenhos). Contudo, antes de apresentar essas imagens, julgo pertinente contextualizá-las.

\section{A escola, a criança e o passado}

\section{Ensino remoto em tempos de pandemia}

Devido à pandemia do coronavírus, no ano de 2020, comecei a entrevistar, de forma remota, professores e professoras que atuam em escolas sediadas em municípios que outrora foram atingidos pela Guerra do Contestado. Nesse contexto, tive a oportunidade de conhecer um pouco da história da Escola Trinta de Outubro, sediada em Lebon Régis-SC, bem como acompanhar, via redes sociais, parte dos projetos que esses profissionais vinham desenvolvendo de forma remota com seus alunos. Na mesma rede social, também seguia a Associação Cultural Coração do Contestado, uma entidade social criada na cidade para divulgar e valorizar o passado da Santa Irmandade entre a população comum.

Essa associação organiza, anualmente, um evento intitulado Semana do Contestado ${ }^{11}$. Ele mobiliza a comunidade escolar e faz parte do calendário oficial

\footnotetext{
${ }^{11}$ Embora configurada como entidade jurídica em 2018, a criação da associação antecede esse ano. Sua principal atividade é a chamada Semana do Contestado. Na página oficial do Facebook consta que, em 2021, ela estará em sua 7ạ edição, portanto, atua pelo menos desde 2014 (ASSOCIAÇÃO CULTURAL CORAÇÃO DO CONTESTADO, 2021).
} 
de Lebon Régis. Por causa da pandemia, a Semana do Contestado, geralmente celebrada durante o inverno (agosto), foi adiada. Para tentar minimizar o impacto da inviabilização da ocorrência do evento, a Associação Cultural Coração do Contestado promoveu um concurso de desenhos sobre o conflito. Ele foi feito em parceria com a Secretaria Municipal de Educação e Cultura. Tratava-se de uma atividade interdisciplinar que contou com a colaboração de todas as escolas sediadas no município. Professores e professoras das áreas de artes, português, história, entre outras, foram mobilizados para incentivar os alunos e alunas a elaborarem um desenho e a publicá-lo na página oficial da associação na rede Facebook. Foi dessa forma que tomei conhecimento de um conjunto de, aproximadamente, 300 imagens, desenhadas, em sua maioria, no formato de papel A4. Um material valioso, visto que trazia a experiência de narrar o passado do Contestado por meio de imagens - longe, portanto, da estrutura tradicional do texto narrativo/dissertativo. Eram desenhos produzidos por crianças, adolescentes, jovens e adultos ${ }^{12}$, narrando o Contestado na perspectiva de quem habita um dos locais que viveu a experiência do mundo igualitário desejado por sujeitos como aqueles que frei Rogério tentou dispersar.

Mergulhar nessas representações infantojuvenis era fundamental para um pesquisador interessado nos vínculos entre passado e presente, isso porque malgrado uma tentativa de atualização da memória do Contestado efetuada por alguns movimentos sociais, via de regra, os municípios do planalto catarinense vivem uma experiência problemática com a história do Contestado ${ }^{13}$. Devido à força de uma campanha de valorização da identidade étnica como vetor do progresso social e econômico de Santa Catarina com forte ramificação na região, geralmente, explora-se e se exalta, antes o suposto pioneirismo dos

\footnotetext{
12 Embora majoritariamente produzidos por crianças e adolescentes, alguns desenhos foram produzidos também por jovens e adultos do EJA. Entre os desenhos infantis, encontramos desenhos de crianças da APAE.

13 Sobre a relação complexa entre os remanescentes do Contestado e a memória da Santa Irmandade, ver Rogério Rosa Rodrigues (RODRIGUES, Rogério Rosa. A solidão das testemunhas: trauma, memória e história do Contestado. In: BORGES, Viviane Trindade; RODRIGUES, Rogério Rosa (orgs.). História pública e presente. São Paulo: Letra e Voz, 2021; e

RODRIGUES, Rogério Rosa. Nas águas do esquecimento: o movimento do Contestado e o dever de memória. In: PRIORI, Angelo; GRUNER, Clóvis Mendes (org.). Contestado: 100 anos de uma guerra sem fim. Curitiba: Editora ANPUH-PR, 2016. p. 29-53).
} 
migrantes e imigrantes europeus, do que a presença indígena, de populações negras e caboclas no meio-oeste catarinense.

Nesse conjunto, o Contestado aparece tanto como fenômeno da bandidagem e do fanatismo, como momento de exaltação da história dos grandes coronéis, políticos e militares que atuaram na repressão ao conflito. Como bem destacado por Emérson Dias de Oliveira e Nilson Cesar Fraga (2016, p. 157), "o nome do município [oficializado em 1959] foi uma homenagem ao catarinense Gen. Gustavo Lebon Régis, que, por ocasião da Guerra do Contestado, era Secretário Geral do Estado de SC e traçou o primeiro ataque a Taquaruçu”. Em que medida os desenhos produzidos no contexto da pandemia tomam posição sobre essas questões? Antes de analisá-los, convém apresentar alguns aspectos históricos de Lebon Régis.

\section{Um municipio em busca de sua história}

O município de Lebon Régis-SC (Figura 1) possui uma população de cerca de 12 mil habitantes (Censo IBGE/2018) e como principais atividades econômicas figuram a agricultura e a pecuária. Conforme notícia do site oficial da prefeitura, "o município é destaque estadual e nacional na produção de diversas culturas, como tomate, alho, maçã, pinus e cebola. Esta, aliás, é considerada a de melhor qualidade do Brasil" (LEBON RÉGIS, 2019). Situado no oeste de Santa Catarina, dista 360 km de Florianópolis. No site oficial, de responsabilidade do município, consta que Lebon Régis (Figura 1) "foi um dos principais palcos da Guerra do Contestado, que é considerado o maior conflito armado brasileiro de todos os tempos” (LEBON RÉGIS, 2019). No mesmo site, é destacado que "as maiores batalhas [do Contestado] aconteceram em terras lebonregenses". Registra-se, ainda, que, em 10 de janeiro de 2018, o município foi reconhecido "legalmente e moralmente" o Coração do Contestado, isso porque, além de ter sediado as "grandiosas batalhas" já mencionadas, "concentra a maior quantidade de sítios históricos referentes à guerra centenária" (LEBON RÉGIS, 2019). 


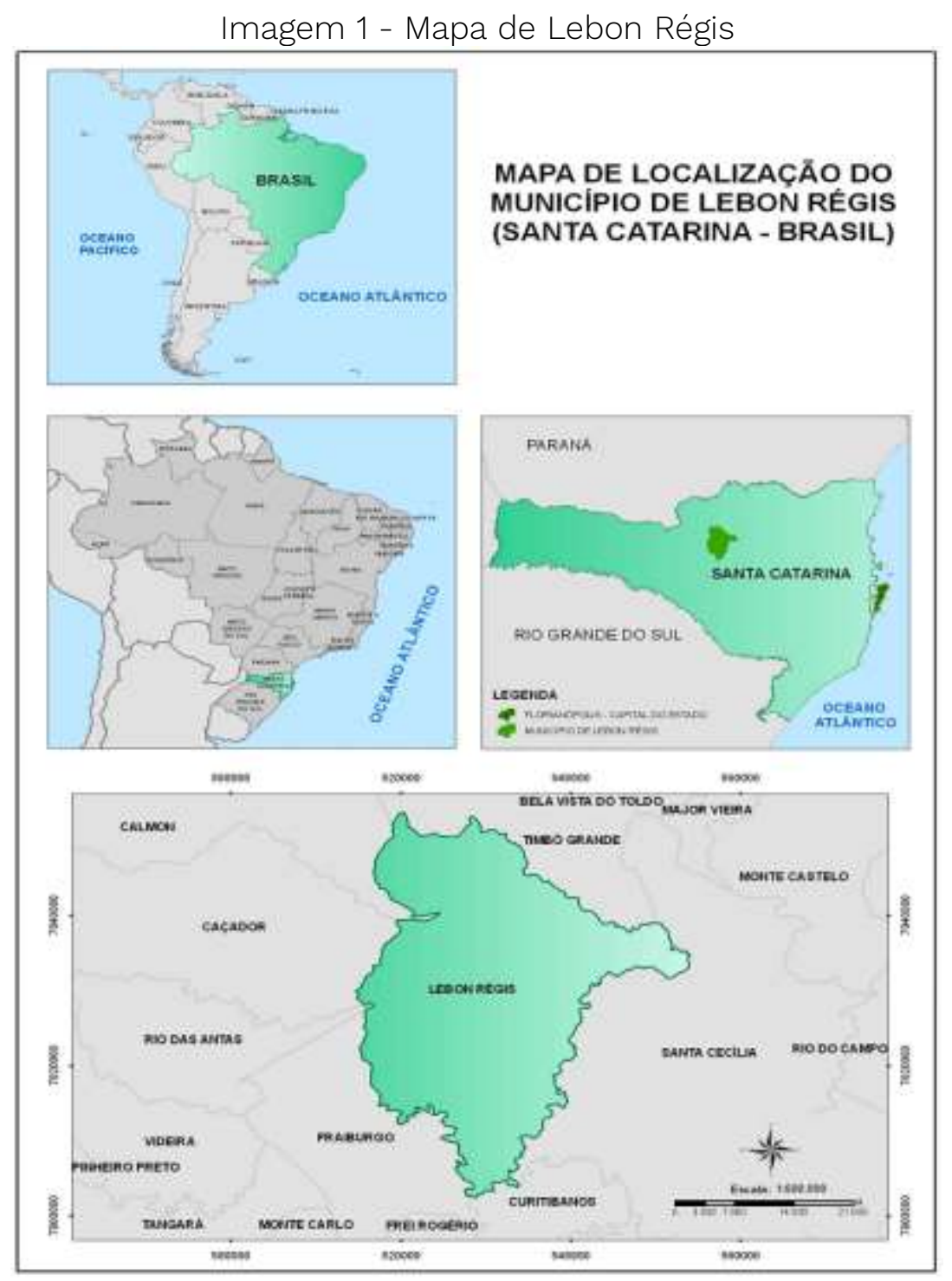

Fonte: Santos (2021).

Apesar de a narrativa alinhar o passado do município a uma perspectiva de história afinada aos grandes feitos e aos grandes monumentos (o que faz parte de uma retórica oficial geralmente comum a órgãos de Estado dessa natureza), interessa destacar que os vínculos entre a história do Contestado e a história do município têm sido fruto de uma ação política muito recente que vai além do exercício político oficial, porque a região conta com dois movimentos expressivos que atualizam a história do Contestado para a comunidade: a Associação Cultural Coração do Contestado e o movimento social de luta pela terra, integrante do Movimento dos Trabalhadores Sem Terra (MST), que tem número significativo de famílias em assentamentos agrários garantidos pelo Instituto Nacional de Colonização e Reforma Agrária (INCRA). 
A Associação Cultural Coração do Contestado ${ }^{14}$ foi criada para promover ações educativas, culturais e turísticas com o objetivo de valorizar a história e a memória do Contestado no município. Essa associação tem um mentor e idealizador importante, o senhor Carlos Silva. Por meio de uma bem-sucedida parceria com a Secretaria de Educação e Cultura de Lebon Régis, bem como com pesquisadores e pesquisadoras da Guerra do Contestado, a associação tem tido um papel importante na configuração de uma nova cultura histórica sobre o evento e seu enraizamento na cultura local ${ }^{15}$. É de sua iniciativa não apenas a busca pela identificação de locais de memória e sítios históricos na região, como também a elaboração do evento, mencionado acima, chamado Semana do Contestado. Ele acontece anualmente e promove festivais de música, dança e teatro, cavalgadas, visitas aos sítios históricos etc. Sua importância é tamanha que entrou para o calendário oficial da cidade e tem ganhado a atenção de profissionais da educação de outros municípios, assim como atraído pesquisadores e pesquisadoras acadêmicos.

Desde os anos 1980, Lebon Régis tem sido palco de atuação de movimentos sociais de luta pela terra. Conforme dados de uma pesquisa coletiva coordenada por Maurício Aurélio dos Santos ${ }^{16}$, a atuação do MST tem contribuído para alterar a estrutura fundiária em Santa Catarina. Em Lebon Régis são 211

\footnotetext{
14 No ano de 2018, a associação foi registrada como pessoa jurídica. Essa oficialização ocorreu para garantir que ela pudesse concorrer a editais públicos e também para delimitar seus objetivos e fins. Seu cadastro como pessoa jurídica pode ser confirmado por meio do site: https://www.informecadastral.com.br/cnpj/associacao-cultural-coracao-do-contestado-

30566778000123. Acesso em: 20 abr. 2021. Para conferir as inúmeras atividades desenvolvidas pela associação antes mesmo de ter sido oficializada com CNPJ, a melhor opção é a página oficial que ela construiu na rede social Facebook. Disponível em: https://www.facebook.com/Coracao.Contestado// Acesso em: 20 abr. 2021.

15 No ano de 2019, fui convidado a participar do I Congresso do Contestado no município de Caçador. Nessa ocasião, o Sr. Carlos Silva participou de uma mesa redonda com lideranças comunitárias e pesquisadores e apresentou a associação para o público. Ao fim do evento, os participantes (alunos e professores) foram convidados a fazer uma visita aos sítios históricos do Contestado situados em Lebon Régis. Na ocasião, fomos acompanhados pelo prefeito do município e o Sr. Carlos foi nosso guia. Relato esse episódio para destacar o trânsito da associação entre o poder político, a universidade, as escolas e os pesquisadores do conflito.

${ }^{16}$ Parte do relatório dessa pesquisa está divulgado na internet: SANTOS, Maurício Aurélio dos. O assentamento Rio dos Patos - Lebon Régis (SC): da luta pela terra à luta como pequeno produtor rural (o contexto histórico). Disponível em: http://www2.fct.unesp.br/docentes/geo/bernardo/BIBLIOGRAFIA \%20DISCIPLINAS\%20GRADUACAO/GEOGRAFIA\%20RURAL\%202016/GRUPO\%20M5/ENG_2006_0 46.pdf. Acesso em 20 abr. 2021.
} 
famílias distribuídas em 7 assentamentos da reforma agrária, tal como disposto na Tabela 1.

Tabela 1 - Distribuição dos assentamentos

\begin{tabular}{|l|l|l|l|}
\hline \multicolumn{1}{|c|}{ Assent. } & \multicolumn{1}{|c|}{ Área (ha) } & \multicolumn{1}{|c|}{ Portaria e data } & \multicolumn{1}{c|}{$\begin{array}{c}\text { Número de } \\
\text { famílias }\end{array}$} \\
\hline Rio Timbo & 718,5432 & $287-01 / 04 / 87$ & 44 \\
\hline Córrego Segredo I & 228,3478 & $906-28 / 06 / 88$ & 15 \\
\hline Córrego Segredo II & 408,5846 & $1393-20 / 10 / 88$ & 26 \\
\hline Rio dos Patos & 844,9900 & $1551-30 / 11 / 88$ & 49 \\
\hline Rio Água Azul dos & 374,8160 & Res. 025-29/04/93 & 26 \\
\hline $\begin{array}{l}\text { Conquista } \\
\text { Palmares }\end{array}$ & 416,1383 & $045-06 / 11 / 96$ & 32 \\
\hline Eldorado dos Carajás & 212,8968 & $03-17 / 02 / 2003$ & 19 \\
\hline Subtotal & $3.204,3167$ & 211 \\
\hline
\end{tabular}

Fonte: Santos (2021, p. 9).

Diante dos números acima, é possível inferir que parte do sucesso econômico do município de Lebon Régis é devido aos agricultores dos assentamentos agrários instaurados na região. São homens e mulheres que lutam contra a concentração fundiária e que, assim como a ramificação do MST no oeste catarinense, reivindicam a memória do Contestado como fator fundamental de luta pela terra. Isso ajuda a compreender parte do destaque que o município possui na agricultura e na pecuária, tão bem destacados no site oficial da Prefeitura de Lebon Régis; mas também nos insere na atmosfera de atualização da luta pela terra que reconhece e valoriza a experiência dos rebeldes do Contestado no interior desses assentamentos. Vale registrar, como exemplo, que, no conjunto das escolas de Lebon Régis, a escola Trinta de Outubro funciona no assentamento Rio dos Patos, a cerca de $15 \mathrm{~km}$ da sede do município. Diante desse contexto, encontrar aproximadamente 300 desenhos, produzidos por estudantes que habitam região por onde viveram, atuaram ou passaram homens e mulheres da Santa Irmandade, informa-nos que não é mera coincidência verificar a força que a memória desse conflito possui na sociedade local, a ponto de se materializar em atividades escolares como o concurso de desenhos de 2020. 
Por fim, do conjunto dos 300 desenhos, proponho destacar 3. Escolha que se deu a partir da problemática construída para esta análise, qual seja, a presença da imagem dialética, tal como concebida por Walter Benjamin, como elemento de suspensão do tempo histórico no momento de seu reconhecimento no presente. Identificar os desenhos infantis como elementos que interrompem aquilo que Benjamin denomina o cortejo triunfal, em que os vencedores espezinham os vencidos, será o desafio a seguir. Em que medida tais desenhos escapam aos estereótipos recorrentemente apresentados em materiais didáticos, afirmados e reafirmados na cultura histórica do Contestado, é o desafio imposto. Além disso, toda a análise foi feita problematizando de que forma esses desenhos foram sensíveis, ou não, aos clamores de sujeitos como Euzébio, Querubina, Manoel e outros mais presentes naquele encontro descrito por frei Rogério Neuhaus.

Para responder a essas indagações, recorri à proposta sugerida por Benjamin de estancar os dois momentos, de torná-los singulares em si, de suspendê-los no tempo. A partir disso, busco compreender em que medida esse encontro não apenas retoma os projetos interrompidos da comunidade que o frei franciscano se empenhou em dispersar, como também atualiza parte dos desejos, ideais e projetos de um mundo igualitário, tal como verbalizados pelos membros da Santa Irmandade que frei Rogério deixou escapar em seu depoimento.

\section{Cartografias sensíveis de uma guerra}

\section{Cena 1: A linha, o corpo e a disposição das coisas}

Como aqueles mapas antigos, que, na tentativa de classificar e representar o mundo além do Mediterrâneo, criaram representações cartográficas onde o em cima e o embaixo dividiam esse mesmo mundo, assim temos o desenho 1. Ele exige do espectador dobrar a cabeça, manusear a folha e prestar atenção aos dois mundos que se confrontam. A alteração da perspectiva, dependente do movimento de manusear o desenho, embaralha a suposta ordem natural das coisas. 
Figura 2. Cartografia da guerra.

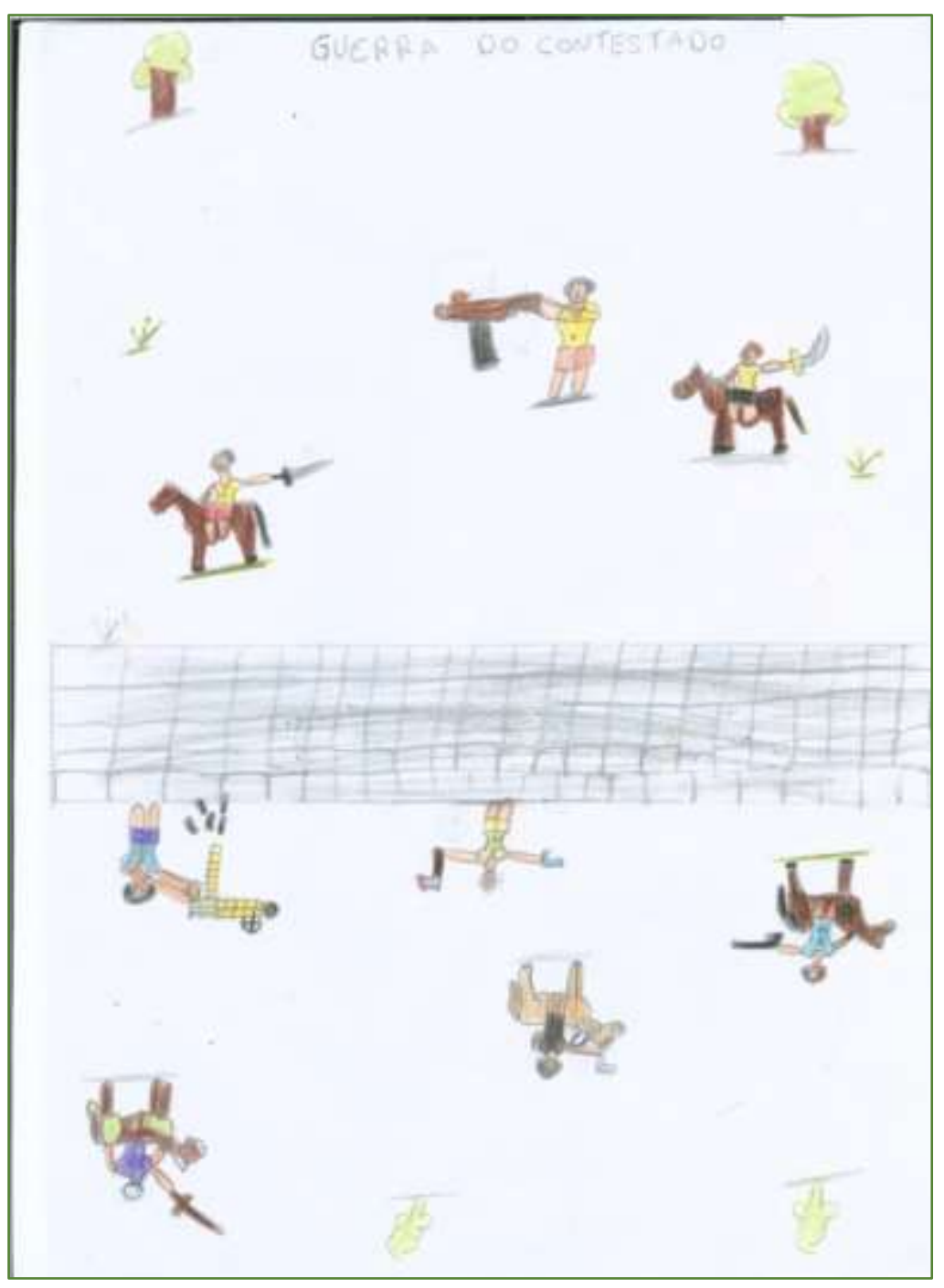

Fonte: Associação Cultural Coração do Contestado (2021).

No desenho 2, os corpos são distinguidos apenas pelas armas que portam: metralhadora, Winchester e até um aeroplano é incluído no cenário de guerra. Entre os fiéis da Santa Irmandade, encontramos espadas e facões, tais como aquelas que aparecem entre os homens e mulheres do lugar. O destaque para a desproporcionalidade do aparato bélico entre os dois grupos já nos situa na crítica possível a quem fala de confronto entre rebeldes e repressores.

O cenário natural aparece totalmente devastado. Vê-se apenas uma ou outra árvore no clarão. A linha da estrada de ferro funciona quase como a Linha do Equador. Ela corta o mapa dessa guerra. Estrada de ferro, que não me parece disparatado dizer, é também aquela citada no documento de 1913 como fonte dos males da região. Animais, plantas, objetos e pessoas são 
cuidadosamente coloridos, incluindo um fio vermelho no machado que se encontra na mão de uma pessoa [sangue de quem?]. A linha férrea é a única que se mantém no grafite frio, sem cores, nem esperança, nem beleza.

\section{Cena 2: Nomear é dar vida}

Figura 3. Ânima.

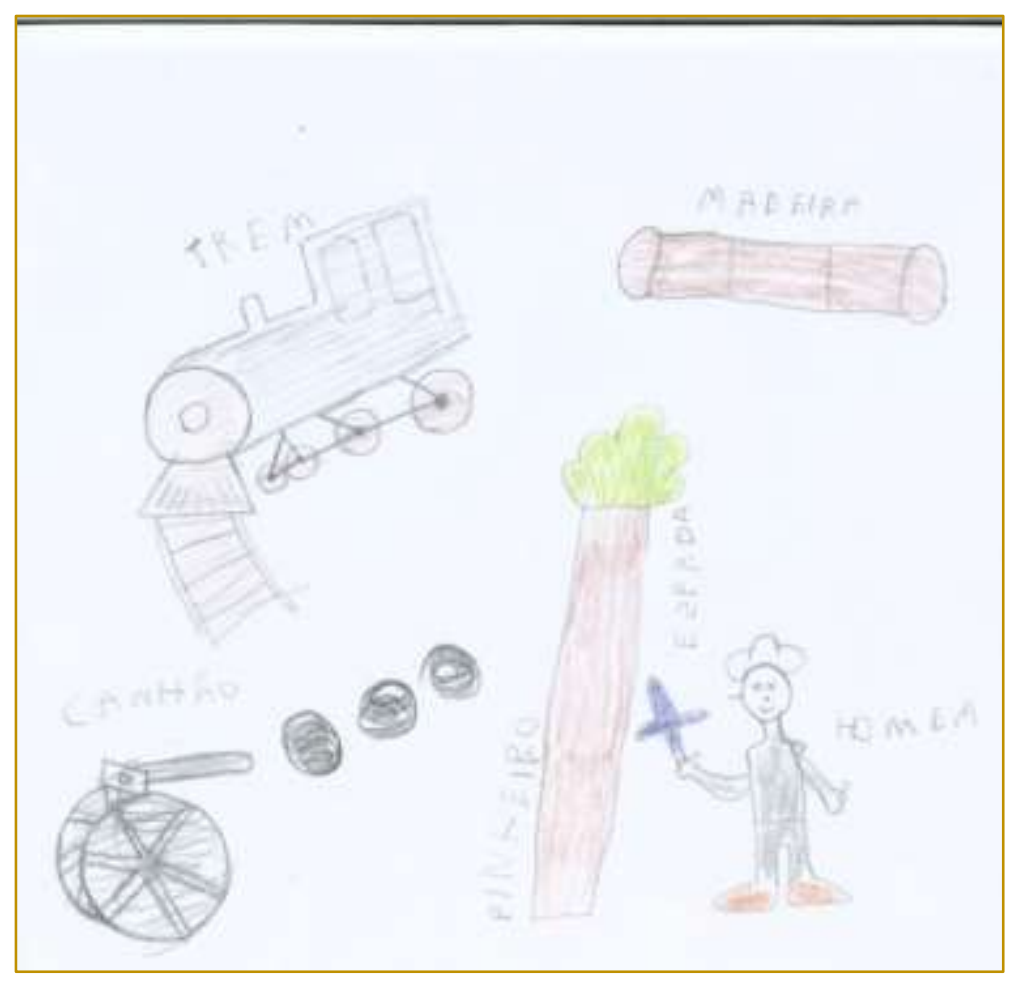

Fonte: Associação Cultural Coração do Contestado (2021).

Todos nós conhecemos uma criança que, diante de um pequeno cavalo de brinquedo que tem na mão, aponta-o para o adulto e diz: CA-VA-LO. Esse me parece um gesto ao mesmo tempo de reconhecimento e de tentativa de dar vida (animar) a esse objeto. Capacidade que crianças exibem com naturalidade. No desenho acima (Figura 3), a criança incluiu na folha de papel elementos aparentemente dispersos: canhão, pinheiro, homem, espada, madeira e trem. Não existe uma forma única de narrar o que esse desenho tem a contar, uma vez que, exceto a afirmação da coisa em si dos objetos, nada está prédeterminado. Proponho o seguinte itinerário de observação: do trem que traz o canhão, do canhão que atira no homem, do homem que se esconde atrás do 
pinheiro com a espada na mão (espada que também é uma cruz) e do pinheiro que é transformado em madeira, e madeira que será transportada nos vagões do trem.

Alguns elementos centrais da luta sertaneja dos homens e mulheres da Santa Irmandade do Contestado aparecem aqui. A desproporcionalidade das armas das forças de repressão comparadas às dos rebeldes, a crítica à devastação dos pinheirais nativos da região que foram transformados em madeira e vendidos para o exterior pela multinacional Southern Brazil Lumber and Colonization Company, o progresso, representado pela locomotiva, como parceiro da destruição e da morte provocada pelas forças de repressão. A percepção infantil chegou antes de a narrativa oficial enaltecer o progresso tecnológico.

Figura 4. Morrer e renascer.

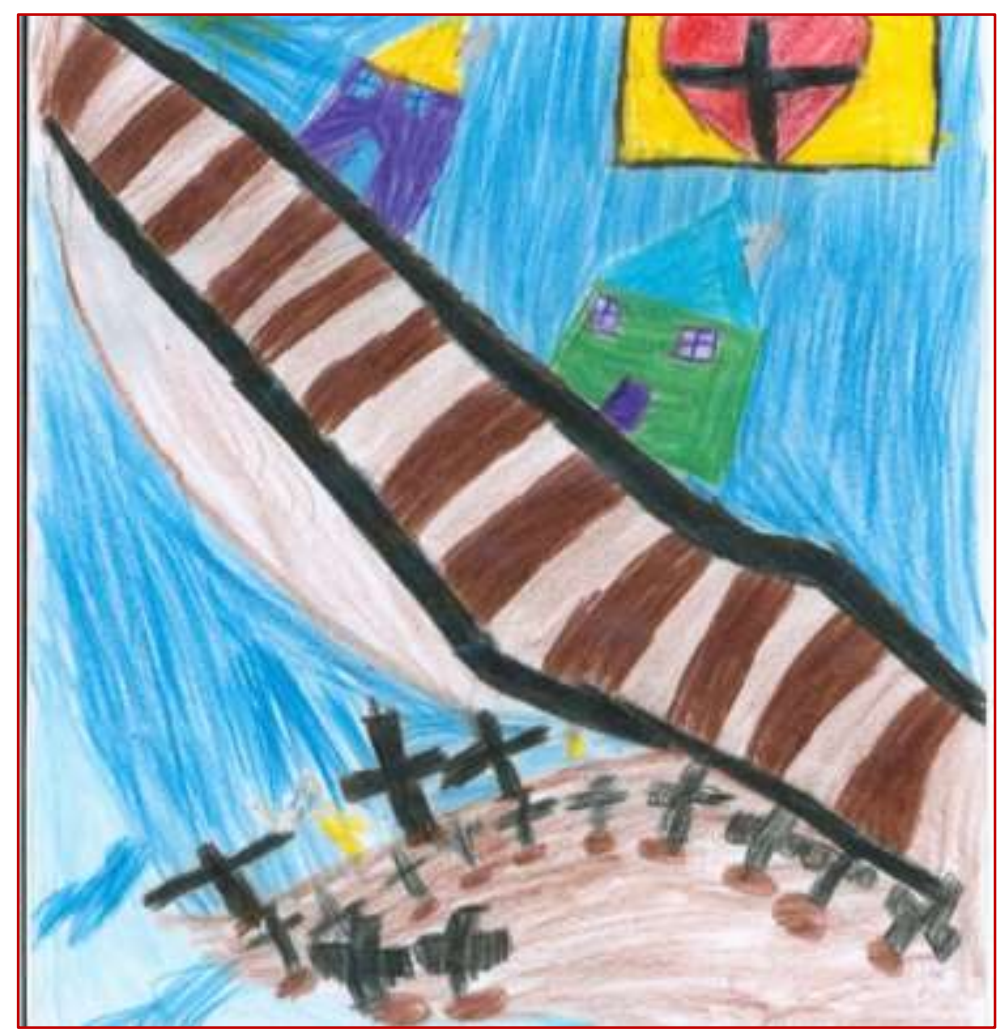

Fonte: Associação Cultural Coração do Contestado (2021). 
O desenho acima (Figura 4), por sua vez, nos arrebata pelas cores. Novamente, duas ordens temporais são apresentadas, tendo como linhas divisórias os trilhos da estrada de ferro. Tal como a representação do globo terrestre, é o azul que predomina. É quase uma forma esférica que se apresenta contornada de azul. Mas de um lado, o século da Santa Irmandade, com suas casinhas simples, quase como a flutuar no universo celeste. Seria esse o tempo da liberdade desejado por Euzébio, Querubina, Joaquim e outros tantos denunciados por frei Rogério? No lado oposto, o azul celeste disputa espaço com o cemitério que abriga os mortos. São valas simples, contendo apenas uma cruz e uma pedra: é o tempo da guerra e da morte.

As cores escolhidas para representar a morte são as mesmas usadas no trilho da estrada de ferro: marrom e preto. Não tem lugar para a vida nessas paisagens: nem gente, nem bicho, nem planta. É o etéreo e o apocalíptico. No entanto, uns borrões amarelos chamam a atenção nos cemitérios. São fantasmas que saem dos túmulos e se dirigem ao etéreo. Fantasmas que representam a esperança de que a morte na luta não foi em vão. Na crença dos rebeldes do Contestado, os caídos em combate não morriam, eles passavam, ou seja, eles se encontravam com os seres celestiais para fortalecer a luta dos seus pares.

\section{História do Tempo Presente e novas temporalidades}

Como tudo isso se relaciona com a HTP, ou mais precisamente, como articular essa história do início do século XX com os pressupostos teóricos e metodológicos da HTP? Seguramente não estamos falando aqui da última catástrofe, categoria balizadora da HTP proposta por Henry Rousso (2016). A ditadura militar brasileira, creio eu, ocupa esse lugar.

Seguramente não existe apenas uma entrada para uma pesquisa em HTP da Guerra do Contestado. As trilhas mais familiares a nós, pesquisadores situados nesse campo de pesquisa, seriam pensar algo como o passado que não passa ${ }^{17}$.

\footnotetext{
17 Rousso (2009, p. 208-209) afirma que "esta concepção de que o passado permanece sempre presente nos apresenta um grande debate, que traz discussão e polêmica, pois é um regime de historicização novo. Não há muitos casos na História, no passado, onde se produziu dessa
} 
Uma experiência que ainda está presente nas rezas, benzeduras, curas pelas ervas, águas santas e tantas outras práticas em que a crença nos monges ainda se faz presente ${ }^{18}$.

Outro caminho seria pelos usos do passado ${ }^{19}$, afinal a história do Contestado tem sido reivindicada pela polícia e pelo exército (sempre no sentido de glorificar seus mortos), assim como pelos filhos e filhas das oligarquias que descendem dos políticos da época ${ }^{20}$. Ainda nessa trilha de usos do passado, poderia abordar a reivindicação que movimentos sociais têm feito da luta pela terra, colocando o Contestado e Canudos como referência e origem.

Há ainda a possibilidade de analisar as múltiplas temporalidades superpostas entre esse passado do Contestado e sua presença na memória e na história atual. Passado que remete a uma experiência do início do século XX, mas que também se enraíza na tradição dos andarilhos e curandeiros que por ali passaram, desde o século XIX. Passado calcado nas práticas de violência e repressão que as elites políticas dirigiram aos movimentos sociais, que antecedem e atravessam o Contestado, nas heranças indígenas e afro-brasileiras presentes nos rituais de cura e na organização social, no recurso à leitura da gesta de Carlos Magno e tantas outras temporalidades a cortar a experiência do Contestado. Esse caminho de análise poderia nos colocar na vereda da HTP a partir das contribuições abertas por Reinhart Koselleck (2014) na forma como analisa o que denomina de "estratos do tempo".

maneira. Entendo que a prática dos historiadores do Tempo Presente não pode ser compreendida fora desse contexto. Não é simplesmente uma maneira de escrever a História Contemporânea, é um pouco mais que isso".

18 Sobre isso, vale destacar os documentários produzidos por Márcia Paraíso, Terra Cabocla (PARAíSO, Márcia. Terra Cabocla. Florianópolis: Plural Filmes, 2015) e A Maravilha do Século (PARAíSO, Márcia. A maravilha do século. Florianópolis: Plural Filmes, 2019), assim como a tese de doutorado de Tânia Welter (2018).

19 Nessa linhagem, podem ser incluídos os trabalhos de Viviane Borges: BORGES, Viviane T. O tempo abre as portas a quem sabe esperar: usos do passado e embates do presente no percurso da exposição realizada na penitenciária de Florianópolis (SC). Esboços, Florianópolis, v. 21, n. 31, p. 236-250, ago. 2014.

${ }^{20}$ Estudos feitos sobre a constituição de museus e arquivos sobre o Contestado no Paraná e em Santa Catarina têm explorado os vínculos entre o desejo de garantir a narrativa do vencedor para além do tempo da repressão ao conflito. Ver: SILVA, Luiz Carlos da. Museu do Paraná e Santa Catarina: formas de lembrar e esquecer a Guerra Sertaneja do Contestado (1912-2012). 2017. Tese (Doutorado em História) - Universidade Federal do Paraná, Programa de PósGraduação em História, Curitiba, 2017. 
Entretanto, como já anunciado, proponho entrar de mãos dadas com Benjamin, o que não significa invalidar outras veredas, mas reconhecer a legitimidade de outras abordagens para problematizar o passado, de forma geral, e o Contestado, em particular. A opção por esse filósofo ocorre por sua particular análise do tempo histórico. Perspectiva que deixa de lado a ideia de processo, de evolução ou mesmo de síntese (no sentido que inaugura uma interpretação final, superior ou definitiva sobre o ocorrido). O que ele entende como tempo-do-agora (Jetztzeit) e imagem dialética oferece oportunidade de ampliarmos o repertório conceitual de abordagem da história de forma geral e da HTP de forma particular. Por isso, eu me deterei um pouco mais sobre essas duas categorias para, em seguida, articular o momento de encontro do frei Rogério com os fiéis de José Maria, em 1913, e os desenhos infantis produzidos em 2020.

O primeiro desafio imposto pela perspectiva de tempo histórico de Walter Benjamin é que ele é abordado como presença e não como um lugar situado em um tempo específico, tampouco como uma força em evolução que nos orienta no presente. Presença que nos chega não como um processo, mas como uma imagem, logo, como um instante preciso que remete a algo que ocorreu, mas que, por diversos motivos, foi interrompido. Isso tem grandes consequências para a abordagem histórica, visto que, como crítico da ideia de progresso social, o filósofo entende que o passado é feito de instantes intemporais que dirigem ao futuro os apelos de tudo aquilo que não foi possível cumprir em seu próprio tempo.

Na tese XIII, ele afirma que "a representação de um progresso no gênero humano na história é inseparável da representação do avanço dessa história percorrendo um tempo homogêneo e vazio" (BENJAMIN, 2005, p. 116)21, ou seja, insistir na ideia de progresso recai na lógica dos vencedores, pois perpetua um sentido de tempo histórico que valoriza ideias como progresso e aperfeiçoamento gradual da humanidade, historicamente construídas por e para determinada classe social. Ao refletir sobre a crítica que Benjamin faz a esse

\footnotetext{
${ }^{21}$ As citações das teses "Sobre o conceito de história" de Walter Benjamin foram recolhidas da versão publicada por Michel Löwy em Walter Benjamin: aviso de incêndio. Uma leitura das teses "Sobre o conceito de história”, com tradução feita por Jeanne Marie-Gagnebin e Marcos Lutz Müller (2005). Qualquer tradução diferente dessa será mencionada em nota de rodapé.
} 
conceito de tempo, Michel Löwy (2005, p. 118) afirma que "o que está em jogo no debate está longe de ser puramente teórico e filosófico. Trata-se, salienta Benjamin, de uma certa atitude prática, que combina o otimismo do progresso com a ausência de iniciativa, a passividade, o imobilismo".

Contra a ideia progressiva e processual da história, o filósofo propõe o kairós, definido por Löwy (2005, p. 119) como “tempo histórico 'pleno', em que cada instante contém uma chance única, uma constelação singular entre o relativo e o absoluto." Esses instantes singulares sobrevivem como imagens estilhaçadas que podem ser recuperadas pela humanidade por meio de certa sintonia entre presente e passado. Para que esse reconhecimento ocorra, é preciso não apenas a afinidade, mas também a tenacidade de saber recuperá-lo em sua fugacidade, já que, como nos alerta o próprio filósofo na tese $\vee$ : “a verdadeira imagem do passado passa célere e furtiva" (BENJAMIN, 2005, p. 62). Isso implica, ressalta Augusto Carvalho (2018), tanto a suspensão da ideia de tempo como progresso quanto a ideia de presente como transição.

Conforme destacado por Francisco Pinheiro Machado, a dimensão éticopolítica dessa concepção de passado é prenhe de consequências: "de um lado, a história não é mais compreendida como mera justaposição cronológica de fatos, mas como uma espécie de busca ou luta no presente pela felicidade" (MACHADO, 2013, p. 25).

$\mathrm{Na}$ esteira do pensamento de Walter Benjamin, a instauração desse instante, o momento da cognoscibilidade, ou o tempo-do-agora (Jetztzeit), não é continuidade com as demandas do passado (o que levaria a operar com a ideia de progresso ou de evolução), nem tampouco uma impressão do presente rumo ao passado (o presentismo). Trata-se de um (re)encontro operado a partir do desejo dos mortos, que, por terem seus projetos suprimidos, apelam para que alguém no futuro os redima daquilo que não conseguiram realizar. Ideia que pode ser encontrada na tese II, na qual o filósofo afirma que "o passado leva consigo um índice secreto pelo qual ele é remetido à redenção”, no que complementa: "se assim é, um encontro secreto está então marcado entre as gerações passadas e a nossa. Então, fomos esperados sobre a terra" (BENJAMIN, 2005, p. 48). 
Trata-se, portanto, de um encontro almejado pelos que foram impedidos de cumprir seus desejos coletivos na construção de um mundo melhor, um encontro que se atualiza a cada dia, que pode ocorrer em uma década, um século ou um milênio. A redenção que ele potencialmente promove é, como nos lembra Löwy (2005, p. 51), "apenas uma possibilidade muito pequena que é preciso saber agarrar".

O tempo do agora é um instante suspenso, congelado, que interrompe o fluxo do progresso e atualiza o passado a partir da irrupção da imagem do passado no presente em momento de perigo. Sua capacidade salvadora se dirige tanto aos vivos quantos aos que já passaram. Segundo se registra na tese VI, o Jetztzeit, nesse sentido, é uma experiência única que se apresenta como o momento exato em que os sujeitos do presente se apoderam de uma lembrança “tal como ela lampeja num instante de perigo" (BENJAMIN, 2005, p. 65). Não se trata de síntese entre dois momentos históricos, nem de evolução, nem de determinação temporal. Conforme interpretado por Augusto de Carvalho (2018, p. 151), é o "limiar não sintético entre o que foi e o que há. O passado de acordo com essa temporalidade do Jetztzeité atualizável; possui a potência de se tornar ato e presença, sempre”.

Se o passado é único e ir-repetível, se ele pode ser acessado por meio de imagens fugidias que irrompem na memória coletiva em nosso tempo, a atualização operada a partir desse encontro, tampouco, será origem e transição para algo no futuro. Como destacado por Carvalho, no fragmento acima, ele pode ser ato e presença. Por isso, também configura uma nova imagem e passa a fazer parte de uma constelação de histórias singulares que é dever do historiador reconhecer.

Nesse aspecto, retomo as reflexões de Augusto de Carvalho ao afirmar que:

A conexão entre passado e presente no tempo do agora de sua cognoscibilidade expressa de modo claro o caráter alquímico da ideia benjaminiana de tempo, pois não há passado puro, muito menos presente puro, mas somente um tempo, o agora de sua cognoscibilidade, cujo funcionamento se explica pelo mecanismo da imagem dialética (CARVALHO, 2018, p. 155). 
Sem passado, tampouco presente puro, o ganho que podemos extrair no reconhecimento desse tipo de operação na HTP é não só em romper com a lógica do tempo homogêneo e vazio de que nos fala Benjamin, mas por nos permitir amplificar os instrumentos e categorias de análise da força viva do passado no presente, retirando-o da sua condição de lugar de verdade, de espaço de acumulação de história ou mesmo de lugar em si que se repete no presente. Como nos lembra o já citado historiador Augusto de Carvalho (2018, p. 168), para este filósofo, "o passado é força, não um lugar".

O Tempo do agora (Jetztzeit) não é, como já dito, um tempo presentista, tampouco um tempo coordenado apenas pelas demandas do presente, menos ainda de um tempo ideologicamente orientado para o momento atual. Mas um encontro que se dá entre presente e passado e que representará a atualização desses dois momentos a partir da imagem dialética. Ainda citando Francisco Pinheiro Machado:

Em cada uma dessas situações atuais de perigo emerge, como um relâmpago, a lembrança de situações de opressão do passado, cujo apelo não satisfeito por libertação ou felicidade ganha nova atualidade, de modo que elas exercem efeito no presente como algo lembrado. Essa tensão é, segundo Benjamin, o verdadeiro objeto do historiador (MACHADO, 2013, p. 29).

Nesse ponto, gostaria de chamar atenção para o quanto Benjamin, em suas teses sobre o conceito de história, exorta o historiador à ação.

E é como um projeto que discorre sobre a dimensão ética e política do trabalho do historiador que gostaria de finalizar a defesa que faço da importância das reflexões de Walter Benjamin para os pesquisadores e pesquisadoras que se situam no campo da HTP. De acordo com Jeanne Marie Gagnebin, na ética proposta por Walter Benjamin incumbe ao historiador o papel de narrador sucateiro, isto é, aquele capaz de recolher os entulhos deixados como despojo pelo vencedor. Ela afirma que "o narrador e o historiador deveriam transmitir o que a tradição, oficial ou dominante, justamente não recorda” (GABNEBIN, 2006, p. 54).

Na tese VI, Benjamin afirma que: "só terá o dom de atiçar no passado a centelha da esperança aquele historiador que tiver apreendido isto: nem os 
mortos estarão seguros se o inimigo vencer. E esse inimigo nunca deixou de vencer" (BENJAMIN, 2005, p. 12)22.

Com essa afirmação, o filósofo nos alerta para a responsabilidade que temos, como historiadores e historiadoras, sobretudo com as vozes silenciadas e para com todas as esperanças interrompidas. Todavia, mais que isso, também com o papel que devemos assumir de interromper a transmissão da versão do vencedor, em não passarmos adiante as narrativas que fazem deles os próceres da história. Na tese VII, Benjamin clama para que não nos identifiquemos com o vencedor, que não nos portemos como os dominadores de turno, ou seja, como "os herdeiros de todos os que, algum dia, venceram" (BENJAMIN, 2005, p. 70). Valendo-nos de uma das muitas imagens formuladas por esse filósofo para se referir ao passado, precisamos interromper o cortejo triunfante dos vencedores, necessitamos interromper a transmissão de suas narrativas, pois elas são não apenas a consolidação da dominação sobre os vivos, mas também a reafirmação da barbárie impingida sobre os mortos.

Diante disso, Benjamin propõe ao historiador abandonar a ideia de neutralidade e, por sua vez, assumir uma posição. Tomar posição, nesse sentido, é abandonar o cortejo dos vencedores e afinar os sentidos para esses instantes do agora, já que eles podem estar ocorrendo no presente. Se, como nos alerta François Bédarida (2003), uma das dimensões importantes da HTP é a responsabilidade ética e moral dos seus profissionais para com as demandas do seu próprio tempo, o que Benjamin vem nos alertar é que, se quisermos interromper o fluxo do homogêneo e vazio que perpetua no tempo e no espaço a vitória do vencedor, precisamos puxar o freio de mão do trem da história e assumir a responsabilidade de trabalhar para que vivos e mortos sejam redimidos das violências que impediram que seus sonhos fossem realizados.

A defesa de que a atividade do historiador é capaz de intervir na realidade, que ela é uma ação política e, como tal, pode ser revolucionária, conecta de forma absolutamente atual o pensamento de Benjamin à HTP, tal como parece ser necessária diante dos ataques ao conhecimento e aos mortos. Soma-se a

\footnotetext{
22 Optei aqui pela tradução de João Barrento. Editora Autêntica, 2016.
} 
isso o desafio de refletirmos sobre em que medida sua concepção de tempo histórico exige o exercício de reconhecer o papel revolucionário que o passado potencialmente tem no presente. Em outros termos, ele confere uma dimensão política ao passado e, por conseguinte, ao historiador, que parece ser um bom instrumento de reflexão aos ataques que a história, os mortos, o passado têm sofrido. Para concluir, retomo algo que o filósofo registrou na tese XVIla:

A chance revolucionária própria de cada instante histórico se confirma a partir da situação política. Mas ela se lhe confirma não menos pelo poder-chave desse instante sobre um compartimento inteiramente determinado, até então fechado, do passado. A entrada nesse compartimento coincide estritamente com a ação política; e é por essa entrada que a ação política, por mais aniquiladora que seja, pode ser reconhecida como messiânica (BENJAMIN, 2005, p. 134).

\section{O encontro do passado com o presente}

Resta agora retomar o momento do encontro do Frei Rogério Neuhaus com os fiéis do curandeiro José Maria, assim como os desenhos infantis produzidos em 2020, para avançar a minha argumentação em defesa da ideia de imagem dialética e tempo-do-agora (Jetztzeit) como uma contribuição importante para ampliarmos as perspectivas temporais da HTP.

O que esses desenhos proporcionam à historiografia é reconhecer uma sutil abertura dos tempos históricos em que os clamores dos mortos, as expectativas, os projetos interrompidos invadem o presente. Contudo, essa apresentação não se faz de forma mecânica, como uma simples pesquisa bibliográfica, tampouco como mera reprodução do que as crianças viram ou ouviram em materiais didáticos ou redes sociais. O que vemos é uma constelação formada por um momento em que os ideais de uma comunidade reprimida são atualizados no presente.

Quem observa esses desenhos com atenção e iniciação aos textos de Benjamin, bem como conhecimento da historiografia do Contestado, vai reconhecer uma irrupção espontânea do sonho dos fiéis daquela época nessas imagens. Algo como uma memória involuntária que relampeja no presente ganha forma na imaginação e se materializa em desenhos filtrados pela sensibilidade 
infantil de crianças que vivem em territórios outrora palco de um sonho comunitário que foi interrompido.

Não podemos esquecer que esses desenhos "aconteceram" no meio de uma pandemia, enquanto um incêndio destruía o Pantanal mato-grossense e lideranças de movimentos sociais de luta pela terra eram assassinadas. Tampouco podemos desprezar o papel ocupado pela escola e seus professores nesse encontro entre os tempos que nos chegam em forma de imagens infantis. Foi da parceria das escolas com a Associação Cultural Coração do Contestado, como também das experiências de luta pela terra do MST, que as crianças foram estimuladas a imaginar o passado da Santa Irmandade. Os professores e professoras incentivaram os estudantes, orientaram a pesquisa em imagens e auxiliaram na composição dos desenhos. A associação deu publicidade a eles, fazendo-os sair do espaço escolar para, via redes sociais, chegar a público distante da comunidade de Lebon Régis. Isso nos remete ao papel fundamental da escola e da educação, mesmo em tempos complexos como o das atividades remotas instaurados por causa da pandemia do coronavírus.

Para além, é preciso ressaltar que a história do Contestado já fazia parte das atividades escolares antes mesmo da proposta que deu origem a esses desenhos. Ela se faz presente nas narrativas dos assentamentos de trabalhadores rurais radicados no município e em regiões próximas. Para muitas famílias assentadas, o Contestado não é apenas um objeto do passado a ser contemplado ou rememorado, é uma experiência de luta de onde provém a força e a esperança de muitos deles em encontrarem dignidade e reconhecimento.

Definir esse encontro como um tempo-do-agora (Jetztzeit) e as imagens que dele brotaram como imagens dialéticas, ou seja, adotar uma perspectiva benjaminiana para abordá-los, é construir novos sentidos onde antes dominava a narrativa dos vencedores. Sentido que pode não ser aquele atribuído pelas crianças ou mesmo pelos professores e demais membros da comunidade. No entanto, essa operação faz parte do papel que o próprio filósofo atribui ao historiador ao afirmar, na tese XVII, que diferente do procedimento aditivo do historicismo, o articulado por um historiador materialista é construtivo: 
Onde o pensamento se detém repentinamente numa constelação saturada de tensões, ele confere à mesma um choque através do qual ele se cristaliza como mônada. Nessa estrutura ele reconhece o signo de uma imobilização messiânica do acontecer, em outras palavras, de uma chance revolucionária na luta a favor do passado oprimido (BENJAMIN, 2005, p. 130).

Seguindo as trilhas interpretativas abertas por Löwy, essas mônadas "são concentrados da totalidade histórica" por onde é possível construir constelações que interrompem a continuidade histórica. Nesse sentido, não cabe tanto a pergunta: será que as crianças sabiam que estavam causando uma fratura no tempo do progresso? Eram conscientes de que, ao fazerem esses desenhos, recuperavam os ideais da Santa Irmandade? O papel de reconhecer esse momento como mônada é do historiador, faz parte de sua tarefa e mesmo de sua obrigação, caso esteja identificado com os desejos não vingados dos sujeitos que, no passado, tiveram seus sonhos interrompidos.

Como registrado por Benjamin na tese VI, “importa ao materialismo histórico capturar uma imagem do passado como ela inesperadamente se coloca para o sujeito histórico no instante do perigo" (BENJAMIN, 2005, p. 65). Inesperadamente, aqui também, pode ser traduzido como: sem que ele [o sujeito] tenha consciência disso ${ }^{23}$. Essa articulação é feita pelo historiador e faz parte de seu compromisso ético e político tanto com os vivos, quanto com os mortos.

Não ter consciência não significa que não possa ser reconhecido ali o sintoma, ou mesmo a presença de algo ${ }^{24}$; sintoma dos desejos dos sujeitos do passado que foram reprimidos, tal como a expectativa dos homens e mulheres da Santa Irmandade que coletivamente interromperam, ainda que momentaneamente, as forças do progresso, da política oligárquica e da religião oficial.

\footnotetext{
${ }^{23}$ A tese de Augusto de Carvalho (2018), já citada acima, faz uma excelente conexão entre o conceito de história de Walter Benjamin e as teorias psicanalítica de Sigmund Freud. Outro intelectual que faz essa articulação é Didi-Huberman (DIDI-HUMERMAN, Georges. Diante do tempo: história da arte e anacronismo das imagens. Belo Horizonte: Ed. UFMG, 2015).

${ }^{24}$ Nos limites deste texto não foi possível desenvolver o conceito de história como sintoma, porém, destaco que autores como Augusto de Carvalho (2018) e Didi-Huberman (DIDIHUMERMAN, Georges. O que vemos, o que nos olha. São Paulo: Editora 34, 1998) têm analisado os conceitos de história de Walter Benjamin à luz de categorias freudianas em que a ideia de sintoma aparece como ponto em comum entre o filósofo e Freud.
} 
Tal reconhecimento do passado como sintoma, percebido nos desenhos infantis por um historiador da HTP, permite que esse profissional construa sentidos ao que foi articulado historicamente, visto que isso se encontra materializado nas narrativas efetuadas pelos desenhos. Entretanto, o sintomático, ou inconsciente, nesses desenhos não é o aparecimento da estrada de ferro, da tecnologia de guerra como o canhão e o revólver na mão do soldado. Esses elementos são inseparáveis das narrativas que os próprios vencedores fazem do Contestado. A irrupção do passado nos desenhos infantis está na forma como a estrada de ferro foi apresentada como antítese do progresso. Ela se manifesta na paleta de cores escolhidas para representar os trilhos da ferrovia como as mesmas do cemitério em que os euzébios, querubinas e manueis estão mortos. A ideia é que o tempo está fraturado pelos trilhos dessa mesma estrada. Aparece na contraposição entre o mundo novo (igualitário, harmonioso e promissor) e o mundo da desordem, da morte e da devastação. Contraposição que se faz tanto pelos sujeitos e objetos incluídos de cada lado, quanto pelas tonalidades que indicam vida e morte nas representações infantis.

Sintoma também pelo fato de tudo isso coincidir com a forma como o velho Euzébio, o menino Joaquim, a velha Querubina e todos os demais homens e mulheres da Santa Irmandade entendiam o mundo e a presença da estrada de ferro. Isso pode parecer pouca coisa, mas se lembrarmos que boa parte do material didático, ou mesmo da cultura histórica sobre o Contestado disponibilizada aos estudantes, não faz mais do que elogiar a modernidade e o progresso ${ }^{25}$, a forma como os desenhos articulam passado e presente não pode ser jogada na vala comum de simples reprodução daquilo que eles leram, viram em materiais ilustrativos da guerra e nas redes sociais. Seus desenhos estão na contramão do cortejo fúnebre que segue espezinhando os mortos, pois eles são críticos a todos os dominadores de turno que seguem fiéis às narrativas dominantes.

\footnotetext{
${ }^{25}$ Rogério Rosa Rodrigues demonstra essa conexão entre material didático e elogio do progresso em análise que fez de material paradidático distribuído pelo governo catarinense em escolas públicas. Sobre o assunto ver: RODRIGUES, Rogério Rosa. Nas águas do esquecimento: o movimento do Contestado e o dever de memória. In: PRIORI, Angelo; GRUNER, Clóvis Mendes (org.). Contestado: 100 anos de uma guerra sem fim. Curitiba: Editora ANPUH-PR, 2016. p. 2953.
} 
O tempo-do-agora (Jetztzeit) instaurado por esses desenhos é arrancado não tanto da lembrança de uma história que, sabemos, foi solicitada como tarefa escolar pelos professores e professoras. No caso dos desenhos infantis, essa potência revolucionária ocorre porque os desenhos permitem contestar outra narrativa dominante: a da escola e da infância como mero lugar e momento de reprodução. Por meio desses desenhos, somos surpreendidos pela criatividade, pela sensibilidade e pela atualização do passado no presente. O encontro dessas crianças com a história do Contestado, materializado nos desenhos, é único, logo, intemporal. Trata-se do momento de cognoscibilidade.

No caso dos desenhos, reconheço afinidades que dizem respeito à violência contra os sujeitos do campo. Afinidades que denunciam, em traços, cores e formas, a exploração política e econômica que motivou a rebelião de homens e mulheres do Contestado. Violência que assombra crianças e adultos que vivem no campo, atravessa os tempos e encontra cúmplices no passado e no presente. Por isso, esses desenhos são ao mesmo tempo singulares e universais, uma vez que, se eles denunciam experiências únicas, não deixam de desejar a redenção de todas essas mazelas. Redenção que parece estender-se para além das fronteiras da região, especialmente quando denuncia a devastação ambiental, os assassinatos de inocentes e a exploração que se metamorfoseia em progresso.

Que a inauguração de um tempo-do-agora (Jetztzeit), tal como aparece nessas imagens, tenha ocorrido na forma do desenho é também algo digno de nota. Uma das questões mais complexas na narrativa da história do Contestado diz respeito à necessidade de dar conta de muitas experiências que se desenvolveram de forma quase simultânea e que também se repetem, portanto, em um tempo expandido que é singular e eterno. Catequizados que somos pela narrativa que privilegia a sucessão dos fatos no tempo, como construir uma escrita que permita falar da estrada de ferro, da madeireira internacional, das empresas de colonização de terras, da tradição dos monges, das disputas políticas locais, dos casos de traição e amor, da exploração da madeira e da ervamate, do coronelismo e das práticas de cura, da presença de imigrantes estrangeiros, afro-brasileiros e descendentes de indígenas dentro e fora da Santa 
Irmandade? Como fazê-lo, repito, de forma a não isolar e hierarquizar cada um desses elementos? Como registrá-lo em uma narrativa que não seja progressiva e acumulativa?

Os desenhos, mais do que textos escritos, permitem efeito de presença nessas narrativas que nos aproximam tanto do universo dessas crianças, quanto da atmosfera da Guerra do Contestado. Ao mesmo tempo, os desenhos se afastam das narrativas que prezam o progresso e a sucessão, assim como escapam do desejo de totalidade, de narrar tudo o que aconteceu e tal como efetivamente aconteceu. Isso porque eles se fixam em instantes precisos daquela experiência histórica e não se furtam em tomar posição sobre ela. Posição que é a da empatia para com os vencidos e que nos chega de forma criativa, em um gesto de brincadeira infantil por meio de desenhos que ressaltam o gosto pelo brincar, sem, contudo, fazer concessões aos "vencedores de turno".

A dimensão criativa da infância, do brinquedo e da educação também faz parte das reflexões de Walter Benjamin. O filósofo destaca que embora o mundo infantil esteja impregnado de mitos, concepções e verdades do adulto, as crianças são capazes de desconstruir essas noções naturalizadas de forma criativa e espontânea. No texto "Brinquedos e Jogos", publicado em 1928, ele afirma que "não poucos dos mais antigos brinquedos (bola, arco, roda de penas, pipa) terão sido de certa forma impostos à criança como objetos de culto, os quais só mais tarde, e certamente graças à força da imaginação infantil, transformaram-se em brinquedos" (BENJAMIN, 2009, p. 96). Transformar-se em brinquedo pode ser interpretado aqui como dessacralizar os objetos ofertados pelo adulto. E isso, afirma Benjamin, se deve "à força da imaginação infantil”.

O autor desconstrói a ideia de que o brinquedo e o brincar sejam uma criação "para a criança" ao invés de uma criação "da criança". Para isso, ele contrapõe, no universo infantil, a ideia de imitação à de repetição, ou seja, ao invés de trabalharmos com a concepção de que o sentido do brinquedo é dado apenas pelos mais velhos, que o ato de brincar é mera imitação do mundo adulto, Benjamin ressalta uma compulsão ancestral da criança pelo jogo, pelo "era uma vez", pela repetição. Ao fazer essa conexão entre repetição e compulsão, o filósofo cita a psicanálise ao dizer, literalmente: 
A obscura compulsão por repetição não é aqui no jogo menos poderosa, menos manhosa do que o impulso sexual no amor. E não foi por acaso que Freud acreditou ter descoberto um "além do princípio e do prazer" nessa compulsão. E, de fato, toda e qualquer experiência mais profunda deseja insaciavelmente, até o final de todas as coisas, repetição e retorno, restabelecimento da situação primordial da qual ela tomou o impulso inicial (BENJAMIN, 2009, p. 101).

Ao voltarmos para os desenhos infantis sobre a Santa Irmandade do Contestado, observamos que o que temos diante de nós não é uma mera imitação do que as crianças viram alhures, mas o prazer pelo recontar uma história, por desmontá-la e dessacralizá-la dos mitos do progresso. Ao narrar o passado do Contestado, repetindo e transformando os símbolos que os adultos construíram para representá-lo, as crianças não apenas assenhorearam-se desse passado, como também jogaram com ele. Nesse sentido, vale outra observação de Benjamin (2009, p. 101) ao afirmar que: "o adulto, ao narrar uma experiência, alivia o seu coração dos horrores, goza duplamente uma felicidade. A criança volta a criar para si todo o fato vivido, começa mais uma vez do início”.

Para além do prazer pela repetição, e o gesto de brincar com o passado, o que mais tem de propriamente infantil nesses desenhos? As cores selecionadas entre a paleta disponível em seus arsenais escolares e a capacidade da imaginação infantil reconfigurar algo apresentado como mito. Como a criança que transforma o cabo de vassoura em cavalo, a bola em boneca e a caixa de papelão em chapéu, o que encontramos nesses desenhos é não somente o resto de uma memória do passado rebelde que sobrevoa a região, como a afirmação de uma criatividade que não deixa de anunciar o que deseja para o mundo em que vive: mais igualdade, menos devastação, fim da violência.

Se as imagens do Contestado elaboradas pelas crianças se apresentam a nós em traços, cores e formas que identificamos como infantis; se elas nos chegam como repetição do já visto, do já ocorrido, é porque foram moldadas não como imitação do passado, mas como irruptiva no presente. O traço, a forma e as cores moldam o conteúdo, e não o contrário. E isso não é um elemento de somenos importância, já que é esse um dos aspectos mais fortes nessa narrativa. É pelo e por causa dos desenhos que mergulhamos no universo do Contestado. Eles são como janelas que se abrem ora para memória, ora para história, ora 
para o passado, ora para o presente. São os desenhos que nos põem em contato com o imaginário infantil e nos permitem identificar elementos involuntários que se conectam com a perspectiva dos fiéis da Santa Irmandade. Nesse sentido, os desenhos são ao mesmo tempo presença do passado no presente e ato de fixação, ou reconhecimento (consciente ou inconsciente) desse encontro no momento de sua efetivação. São também, como já dito, desejos e esperança de um mundo melhor.

\section{Considerações finais}

A infância é o lugar da criatividade, da sensibilidade e da intuição. Nem sempre essas qualidades se manifestarão na criança, mas, uma vez trabalhadas, uma vez estimuladas social e coletivamente, elas podem garantir bons frutos. Quando Benjamin fala de uma memória involuntária que relampeja no presente e é por ele reconhecida, penso que esse reconhecimento exige certa predisposição, certa sensibilidade que a infância potencialmente guarda em si de forma privilegiada. É pela intuição que esse lampejo fugidio do passado pode ser captado no momento de perigo do presente. Como filósofo que antropofagiza o materialismo, Walter Benjamin não despreza o fato de que tais elementos, que podem entrar na conta do que ele denomina de espirituais, precisam ser associados aos materiais. Na tese IV, sobre o conceito de história, Benjamin afirma que "a luta de classes, que um historiador escolado em Marx tem sempre diante dos olhos, é uma luta pelas coisas brutas e materiais, sem as quais não há coisas finas e espirituais" (BENJAMIN, 2005, p. 58). Ao formular essa tese, o filósofo não faz oposição, nem hierarquização, entre as condições materiais e espirituais. O que ele propõe é uma ética de pesquisa que convida o historiador a não desprezar em sua análise fatores como coragem, humor confiança, astúcia, firmeza e, acrescento, intuição.

Diante desse alerta, vale a pergunta: como ter disposição para estudar, desenhar, reconhecer e reconhecer-se na luta dos rebeldes do Contestado com fome, sem teto, sem saúde, sem escola? Para que encontros entre passado e presente, como o registrado nos desenhos infantis sobre o Contestado, sejam possíveis, é preciso assegurar que as crianças de hoje tenham casa, comida, terra, 
brinquedo, transporte, isto é, que tenham as condições materiais sem as quais não teriam as refinadas e espirituais condições necessárias para chegar a tempo nesse encontro prometido há mais de um século por figuras como o velho Euzébio, o menino Manoel, a velha Querubina e demais homens e mulheres que se reuniram em Taquaruçu, em 1913, para fundar o novo tempo do mundo.

Se pensarmos que a vitória dos vencedores do Contestado tem sido também uma vitória da memória e da narrativa, o que se apresenta nesses desenhos é uma presentificação das demandas dos rebeldes, capaz de capturar nossa atenção, direcionar nosso olhar para a luta, criar uma fenda capaz de questionar as narrativas vitoriosas dos dominantes. Elemento que, creio, pode ser potencializado pela aliança entre a escola e a universidade, entre o ensino de história e a historiografia. Quando essa historiografia é comprometida ética e politicamente com os sujeitos do passado, quando ela se conjuga com alguns pressupostos básicos da HTP, ela pode cumprir o papel que Benjamin profetizava para a parceria entre materialismo e teologia.

O encontro do passado com o presente em sua configuração como imagem dialética não é tão simples de acontecer, pois mais fácil é seguir o cortejo das narrativas vigentes, especialmente quando elas se multiplicam em espaços acessíveis aos estudantes como redes sociais e até mesmo alguns locais de memória que trazem consigo narrativas prontas que mais se identificam com o vencedor do que com os sonhos dos homens e mulheres que tiveram seus projetos interrompidos. Reconhecer que esse encontro ocorreu a partir da perspectiva infantil, que foi capturado por crianças, aliás, por filhos de homens e mulheres que lutam pela terra e que habitam uma fatia de chão, outrora ocupado por sujeitos do Contestado, tem algo a nos dizer sobre o papel da escola e da infância no mundo contemporâneo. Que a HTP possa estar preparada para registrar esse momento me parece uma tarefa tão urgente quanto necessária. 


\section{Referências}

ASSOCIAÇÃO CULTURAL CORAÇÃO DO CONTESTADO. VII Semana do Contestado. Lebon Régis, SC, 20 jan. 2021. Facebook: ACCC. Disponível em: https://www.facebook.com/Coracao.Contestado/photos/a.134074401695266/221 951839574188/ Acesso em: 15 jun. 2021.

BÉDARIDA, François; MUC, Gabrielle; TREBITSCH, Michel. Histoire, critique et responsabilité. Bruxelles: Complexe: IHTP: CNRS, 2003.

BENJAMIN, Walter. Sobre o conceito de história. In: LÖWY, Michael. Aviso de incêndio: uma leitura das teses "sobre o conceito de história". Tradução: Jeanne Marie Gagnebin; Marcos Lutz Müller. São Paulo: Boitempo, 2005. p. 41-146.

BENJAMIN, Walter. Sobre o conceito de história. In: BENJAMIN, Walter. O anjo da história. Tradução, notas e comentários: João Barrento. 2. ed. Belo Horizonte: Autêntica, 2016. p. 8-24.

BENJAMIN, Walter. Reflexões sobrea a criança, o brinquedo e a educação. Tradução: Marcus Vinicius Mazzari. 2. ed. São Paulo: Ed. 34, 2009.

BUCK-MOORS, Susan. O presente do passado. Florianópolis: Cultura e Barbárie, 2018.

CARVALHO, Augusto de. História do "passado": da conceitualização tradicional à reconfiguração em Walter Benjamin, Martin Heidegger e Sigmund Freud. 392 f. 2017. Tese (Doutorado em História) - Universidade Federal de Minas Gerais, Faculdade de Filosofia e Ciências Humanas, Belo Horizonte, 2017.

DALLANORA, Cristina. Conflitos no ex-Contestado: coronelismo e bandoleirismo numa região de fronteira. 2019. (Doutorado em História) - Universidade Federal de Santa Catarina, Florianópolis, 2019.

GAGNEBIN, JeanneMarie. Lembrar, escrever, esquecer. São Paulo: Editora 34, 2006.

GALLO, Ivone Cecília D’Ávila. O Contestado: o sonho do milênio igualitário. Campinas: Editora da UNICAMP, 1999.

KARSBURG, Alexandre. O eremita das Américas: a odisseia de um peregrino italiano no século XIX. Santa Maria: Editora da UFSN, 2014.

KOSELLECK, Reinhart. Estratos do tempo: estudos sobre história. Rio de Janeiro: Contraponto: PUC-Rio, 2014.

MACHADO, Francisco Pinheiro. Imagem e consciência da história: pensamento figurativo em Walter Benjamin. São Paulo: Loyola, 2013.

MACHADO, Paulo Pinheiro; Axt, Gunter (org.). Processo de Adeodato, último chefe rebelde do Contestado. Florianópolis: CEJUR, 2017. 
MACHADO, Paulo Pinheiro. O contestado na sala de aula. Cadernos do CEOM: cultura e sociedade, Chapecó, v. 30, n. 46, p. 73-80, jun. 2017.

MENEZES, Celso Vianna Bezerra de. Irani: uma batalha entre mundos. In: VALENTINI, Delmir; RODRIGUES, Rogério Rosa (orgs.). Contestado: fronteiras, colonização e conflito (1912-2014). Porto Alegre: Letra e Vida; Chapecó: Ed. UFFS, 2015. p. 114-129.

MONTEIRO, Duglas Teixeira. Os errantes do novo século. São Paulo: Duas Cidades, 1974.

LEBON REGIS. Seja bem vindo(a) ao coração do Contestado. Lebon Régis: Prefeitura Municipal, 2019. Disponível em: https://www.lebonregis.sc.gov.br/cms/pagina/ver/codMapaltem/50313. Acesso em: 21 abr. 2020.

SANTOS, Maurício Aurélio dos. O assentamento Rio dos Patos - Lebon Régis (SC): da luta pela terra à luta como pequeno produtor rural (o contexto histórico). Disponível em:

http://www2.fct.unesp.br/docentes/geo/bernardo/BIBLIOGRAFIA \%20DISCIPLINAS\%20GRADUACAO/GEOGRAFIA\%20RURAL\%202016/GRUPO\%20M 5/ENG_2006_046.pdf. Acesso em 20 abr. 2021.

SINZIG, Pedro. Frei Rogério Neuhaus. Petrópolis: Editora Vozes, 1934.

OLIVEIRA, Emerson Dias de; FRAGA, Nilson Cesar. Lebon Régis, da vivência cabocla no Contestado ao sufocamento na lógica agrário-capitalista. Tamoios, São Gonçalo, ano 12, n. 2, p. 150-170, jul./dez. 2016.

ROUSSO, Henry. Sobre a história do tempo presente. [Entrevista cedida a] FAVERO AREND, Silvia M.; MACEDO, Fabio. Tempo e Argumento, Florianópolis, v. 1, n. 1, p. 201-216, 2009. Disponível em:

https://www.revistas.udesc.br/index.php/tempo/article/view/705. Acesso em: 21 abr. 2021.

ROUSSO, Henry. A última catástrofe: a história, o presente, o contemporâneo. Rio de Janeiro: Ed. FGV, 2016.

WELTER, Tânia. Encantado no meio do povo. São Bonifácio: Edições do Instituto EgonSchaden, 2018.

Universidade do Estado de Santa Catarina - UDESC

Programa de Pós-Graduação em História - PPGH

Revista Tempo e Argumento

Número Especial - 2021 tempoeargumento.faed@udesc.br 